\title{
New Evidence for the Dates of the Walls of Jerusalem in the Second Half of the Second Century BC
}

Donald T. Ariel

Israel Antiquities Authority

\begin{abstract}
Alongside a critique of a new analysis of Josephus' long account of Antiochus VII Sidetes' siege of Jerusalem in his Antiquities, this paper presents new archaeological support for the conclusion that, at the time of the siege, the "First Wall" enclosed the Southwestern Hill of the city. Further examination of the stratigraphic summaries of the Hellenistic fortification system at the Giv'ati Parking Lot proposes that the system constituted part of the western city-wall for the City of David hill. The addition of a lower glacis to the wall was made in advance of Sidetes' siege. In other words, in addition to the "First Wall" protecting the western side of an expanded Jerusalem, John Hyrcanus also reinforced the City of David's wall, as an additional barrier to the Seleucid forces. Later, after the high priest's capitulation to Sidetes (132 BC) and the king's death in Media (129 BC), Hyrcanus again reinforced the same fortification with an upper glacis, which never was tested.
\end{abstract}

Keywords: Jerusalem, "First Wall”, Southwestern Hill, Giv‘ati Parking Lot, Antiochus VII Sidetes, John Hyrcanus.

\section{Introduction}

In understanding human settlement, size is a basic jumping-off point. However, for a large ancient settlement to be defined as a city, it must also have a defensive wall around it. Tracing the growth and decline of a city has often been undertaken by measuring the amount of land within its city-walls. Consequently, archaeologists and historians alike have been preoccupied with city-walls. Archaeologists are happy to have written sources at their disposal in their quest to date the fragments of walls that are found, while historians rely on archaeologists to determine the dates of those city-walls, thus often creating circular arguments.

For Jerusalem, there have been minimalists and maximalists who have taken stands on the size of Jerusalem in its various periods of occupation. They clutch at straws to prove their positions, but the cards are reshuffled when a significant new stretch of city 
wall is uncovered in an excavation. Historians and archaeologists alike then scramble to reinterpret the written record according to their points of view. An example from 20 years ago is the extramural neighborhood excavated on "Rothschild's Land" on the eastern slope of the City of David hill. As I was preparing the publication of an excavated portion of that neighborhood, another team uncovered a new city-wall further east, closer to the bottom of the Kidron Valley. A textual search uncovered verses in 2 Chron. (32.5) and Isaiah (22.11) to help explain what had been found and the discussion of the extramural neighborhood was solved by positing that, before the new wall was built, in times of siege the inhabitants of that neighborhood would move to within the more secure defenses of the mid-slope city-wall. ${ }^{1}$

Indeed, in the Iron Age and in the Hellenistic Period, the city expanded to include part or all of the hill to the west and south (the Southwestern Hill). For the Hellenistic Period, the date of the expansion has consensually been placed in the second half the second century $\mathrm{BC},{ }^{2}$ based upon stratigraphy and a number of artifact categories found on the hill (primarily ceramics, including local wares and both imported and locallystamped storage jar handles. ${ }^{3}$ As for the date of the fortification of that hill, whereas once Alexander Jannaeus was a candidate for fortifying the Southwestern Hill in his reign, ${ }^{4}$ today the consensus places the fortification only in the second half of the second century $\mathrm{BC}$.

The subject of this paper is the evidence for two contemporaneous fortification lines in Jerusalem in the second half of the second century BC, one surrounding only the City of David and another wall built to include the new western neighborhoods.

As is often the case for Hellenistic-period Jerusalem, our starting point is the historian Josephus, who, on the eve of the revolt that destroyed the city, took pause and described the capital's fortifications at that time. "The city was fortified by three walls... Of the three walls, the most ancient, owing to the surrounding ravines and the hill above them on which it was reared, was well-nigh impregnable. But, besides the advantage of its position, it was also strongly built, David and Solomon and their successors on the throne having taken pride in the work" (Jos. AJ 5.136-143). Josephus proceeded to describe the other two walls as they stood in $66 \mathrm{AD}$. He understood the "First Wall" that he described to be the oldest, and therefore credited David and Solomon as the first to build it. Today it is consensual that this was not the earliest wall built in Jerusalem, and that the city was fortified, at the least, in the Middle Bronze and Iron Ages. Despite recent naysayers, it is still accepted that the city-walls of at least some of those earlier periods enclosed only the City of David hill. This study will present new examinations of the historical evidence for the "First Wall," new archaeological evidence for the dating of that wall, and a discussion of the recently identified western fortification line around the City of David hill.

Ariel - De Groot 2000, 160-163.

2 Geva 1985, 30; Geva 2003, 526-535; Lipschitz 2012, 159.

3 Geva 2018, 34-36.

4 E.g., Avigad 1980, 74. 


\section{Before the Second Century BC}

As background for the second century $\mathrm{BC}$, the relevant early archaeological finds need to be summarized. The City of David hill was enclosed by a wall by the eighth century BC. By the end of that century not only were walls added to the east, towards the Kidron Valley (above), but also to the further west, as part of a network that included the so-called "Broad Wall" uncovered in today's Jewish Quarter. This latter large addition to the size of the city was relatively short-lived. Certainly after the Jerusalem's destruction in 586 $\mathrm{BC}$ the city returned to its original configuration, on the City of David hill only.

For the Persian Period there are biblical traditions of repairs to a city-wall in the fifth century BC (Neh. 1.3), but that wall's very existence is uncertain, and there is no consensus on any of the proposed archaeological indications for it.

Reference to fortifications around Jerusalem is found in the Letter of Aristeas (or Pseudo-Aristeas), set in the third century BC. However, the descriptions of Jerusalem in the composition, if historical at all, are now thought to reflect a much later period, perhaps the end of the second century BC. ${ }^{5}$

\section{During the Second Century BC}

There has been a plethora of published research on Jerusalem's city-wall and other fortifications in the Hellenistic Period. ${ }^{6}$ I will regard the most recent summary of the subject at hand, an article by Hillel Geva published in 2018, as presenting the current archaeological consensus. My focus will be Geva's section entitled "Who Built the First Wall around the South-Western Hill and When?" (pp. 43-45), where the author concluded that "the wall surrounding the south-western hill was built in the days of Simon Thassi or John Hyrcanus I or both, between 141 and 133/132 BCE" (p. 45).

In 1 Macc, whose composition is generally dated to after $129 \mathrm{BC}$, but whose historical setting begins in the reign of Antiochus IV (175-164 BC), there are many references to city-walls in Jerusalem (1 Macc 4:60; 6:7; 6:62 [Judas]; 10:11; 10:45; 12.36-37 [Jonathan]; 13:10; 14:37 [Simon]). Honigman saw the city-wall restorations descriptions as a repeating narrative theme in $1 \mathrm{Macc}$, related to the major template in both books of Maccabees, temple foundation (or refoundation). ${ }^{7}$ She saw a prototype for this during Nehemiah's rule, when the Persian-period governor is described as engaging in wall-building, which "could easily be seen as a symbolic extension of the temple, since after its completion it marked the physical boundary separating the ingroup from outsiders." In 1 Macc, Honigman determined that the "legitimizing activity" of wall reconstruction appears in the narratives of all three protagonist brothers,

5 Bar-Kochva 1996, 271.

6 Mercifully, the discussion here will barely touch upon the thorny, still-unresolved question of the location of the Akra, with its numerous proposals and almost boundless literature.

7 Honigman 2014, e.g., 122-141.

8 Honigman 2014, 111. 
Judah, Jonathan and Simon, ${ }^{9}$ and the same trope is also cited for John Hyrcanus at the very end of 1 Macc (16:23-24). ${ }^{10}$ As a trope, wall construction is also counterposed by the city-wall demolition of the enemy ${ }^{11}$ and the building of the great strong wall of the

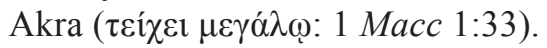

The employment of these and other motifs, and the determination of cyclicity in the texts ${ }^{12}$ had, for the author, the result of implying that the historicity of elements contained there should be brought into question. ${ }^{13}$

There may or may not be a connection between Honigman's literary analysis of the first two books of Maccabees and some recent archaeological discourse. It may be noted, however, that a year after the publication of Honigman's volume, Ben-Ami and Tchekhanovets, in a preliminary report of the find of a city-wall fragment, appended tower and glacis at the Giv'ati Parking Lot (hereafter, GPL), considered only the possibility that those elements were part of a Seleucid fortification, possibly the Akra. ${ }^{14}$ They did not consider the possibility that those remains could also be identified as any of the Maccabean-Hasmonean fortifications or refortifications described in 1 Macc. More recently, the newest excavation team at the site where Ben-Ami and Tchekhanovets had excavated have implied (in what may alternatively be simply poor wording on their part) that the there is no undisputed archaeological evidence for a city-wall in Jerusalem between the eve of Jerusalem's destruction in 586 BC and an unnamed city-wall constructed by "the late Hasmonean kings." 15 While it is true that undisputed archaeological evidence is a scarcity, there should be no doubt that during those almost four centuries, at least for one point in time, there was a city-wall surrounding Jerusalem. I am referring to the wall besieged by the Seleucid King Antiochus VII Sidetes' army at the end of the second third of the second century BC. ${ }^{16}$

Among the unexpectedly numerous accounts of the siege of Jerusalem by Antiochus VII Sidetes, ${ }^{17}$ none is more detailed than that in Josephus' Antiquities (13.236-252), where the city wall is explicitly referred to twice. The first citation describes the placement of the siege engines: "... on the north side of the wall, where the ground happened to be level, [Sidetes] erected a hundred towers (Jos. AJ 13.238). The second time is when Sidetes "pulled down the walls encircling the city"18 as he "raised the siege and withdrew” (Jos. AJ 13.248).

9 Honigman 2014, 168.

10 Honigman 2014, 176.

11 E.g., 1 Macc 1:31; Honigman 2014, 199.

12 Honigman 2014, 160-161.

13 Honigman's denial of the factuality of Antiochus IV's religious persecutions has received the most pushback: Bar-Kochva 2017; Kosmin 2018, 227-228.

14 Ben-Ami - Tchekhanovets 2015, 321-322.

15 Shalev et al., forthcoming.

16 The siege of Antiochus VII of Jerusalem was the only siege of the entire city in the second century BC. Beforehand, Antiochus III, Sidetes' great grandfather, had only besieged the citadel of Jerusalem (conceivably just northwest of the Temple compound).

17 Britt - Boustan 2017, 67.

18 "Wall" is given as $\sigma \tau \varepsilon \varphi \alpha ́ v \eta \nu$ (crown/battlement). It is more likely, however, that the wall was breached and not systematically razed: Bar-Kochva 2010, 410, note 30. 


\section{Sidetes' Siege}

Josephus' Antiquities accounts of the early Maccabean period entailed consistent paraphrasing of 1 Macc. ${ }^{19}$ However, in his narrative of the siege of Jerusalem by Antiochus VII Sidetes, Josephus did not paraphrase $1 \mathrm{Macc}$, but rather fused two conflicting sources, according to an in depth source-critical analysis made by Bar-Kochva. ${ }^{20}$ The asynchronism in the first passage in his narrative ("[Antiochus] invaded Judaea in the fourth year of his reign and the first of Hyrcanus' rule, in the hundred and sixtysecond Olympiad"; Jos. $A J$ 13.236) already suggests the complexity of the narrative. Josephus' new sources were certainly not Jewish. ${ }^{21}$ Each of the two sources presented different versions of the same event (a "long siege story" $[A J]$ and a "short siege story" [BJ]). The Bellum Judaicum account derived from Nicolaus of Damascus. In Antiquities the source was Strabo, whose own source was Posidonius of Apamea. Josephus interwove his narrative in Antiquities from both Nicolaus of Damascus and Strabo.

Another layer of complexity is added in Bar-Kochva's analysis, whereby he identified a source for Posidonius' narrative: Timochares (2010, 458), a "court historian of Antiochus VII, or at least a person close to the court," ${ }^{22}$ someone who may possibly have been a witness to the Sidetan siege. Timochares is also someone for whom a fragment survives from his work on Sidetes' life, On Antiochus. ${ }^{23}$ This allows a good explanation, but perhaps not the only one, for the unexpected amount of detail in Josephus' "long siege story."

No doubt, the unusual depth of detail transmitted by Josephus of the progress of the siege must have had a kernel of historical veracity. However, there were many opportunities for Timochares' account to be redacted to reflect the views of those (Posidonius, Strabo, Josephus) in the line of transmission of those details. Nonetheless, owing to the wealth of detail in another surviving fragment of Timochares and in the Antiquities text, both the fragment and the "long siege story" have been mined for information. ${ }^{24}$

I will discuss the relevant issues regarding the Antiquities account later in this paper. For our purposes now, it may be said that many of the specifics found in the narrative cannot be taken at face value.

19 Bar-Kochva 1989, 165.

20 Bar-Kochva 2010, 404, 415.

21 Bar-Kochva 2010, 401-402.

22 Bar-Kochva 2010, 458.

23 The fragment is preserved in fourth-century AD Eusebius' Praeparatio evangelica (9.35) who in turn said he copied it from Alexander Polyhistor's Jewish anthology: Bar-Kochva 2010, 466. Bar-Kochva considered the fragment part of a much longer narrative about Sidetes' siege of Jerusalem in Timochares' biography of the Seleucid king.

${ }^{24}$ Other accounts, of lesser importance to our subject, are those of Diodorus Siculus (whose source is consensually considered to have been Posidonius of Apamea; Bar-Kochva 2010, 409-412, 435), Plutarch, Tacitus, and Porphyry. 


\section{New Archaeological Information Regarding Sidetes' Siege}

There are three new categories of archaeological remains today that have an impact on the dating of the Hellenistic-period fortification lines in Jerusalem (Fig. 1). Each may be said to have a two aspects, a geographical aspect and a material aspect. The first new category has as its geographical aspect the partially exposed floor uncovered in excavations of Sivan and Solar at the so-called David's Citadelel ${ }^{25}$ in 1982-1983. The material aspect of this category is a particular group of bronze arrowheads.

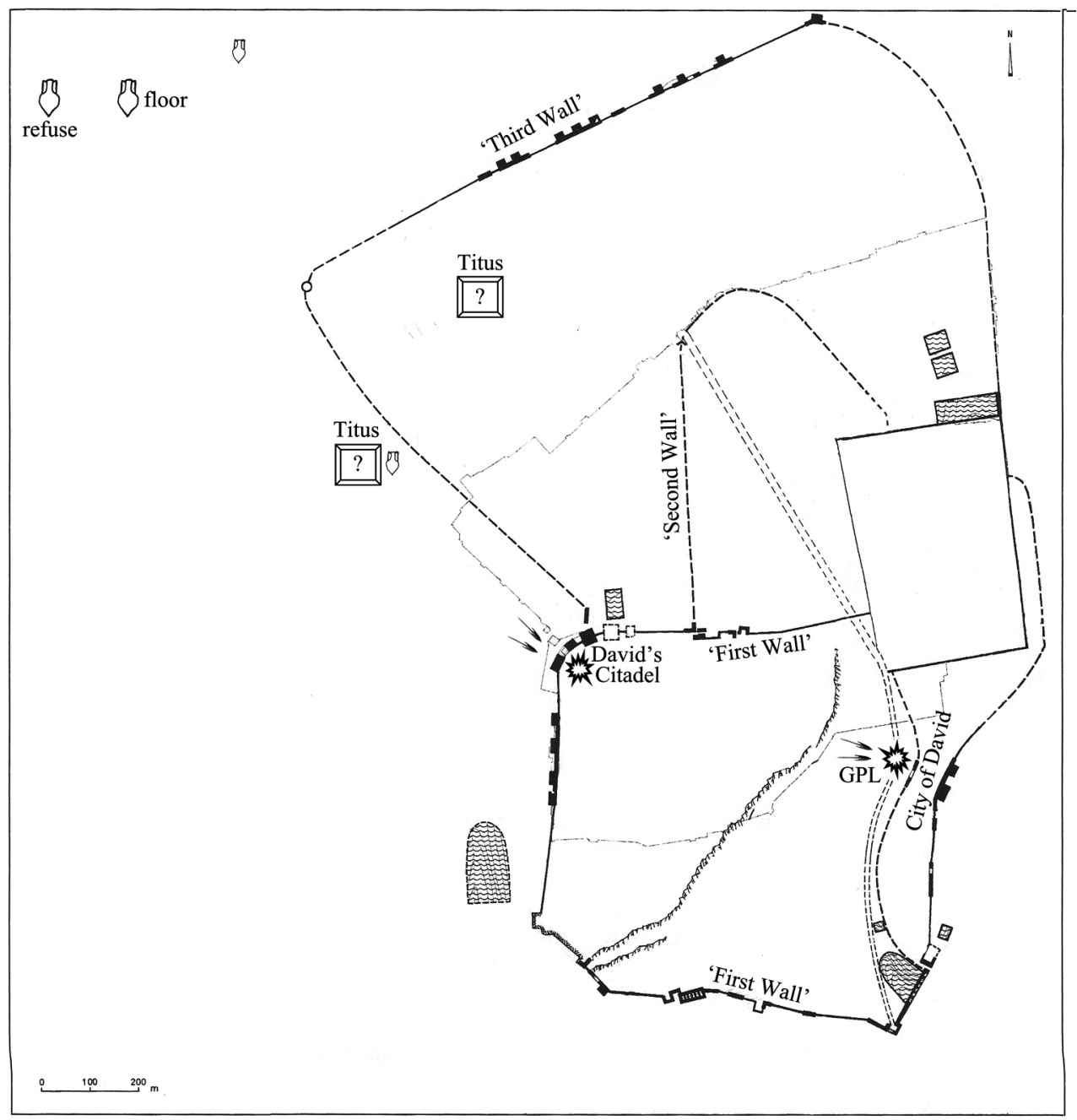

Fig. 1. Map of Jerusalem in the second half of the second century $\mathrm{BC}$ Based upon map in Geva 2011, 300, Fig. 1. For orientation, lines of the Ottoman Old City, the "Second" and "Third" walls, the Herodian temenos and some other anachronistic features are provided.

25 This is the term I am using for the Tower of David / Jerusalem Citadel complex adjacent to the Jaffa Gate. 
The geographical aspect of the second new category is the fortification system excavated in 2011-2015 at the GPL; $;{ }^{26}$ its material aspect is coins. The first reports about the fortification system appeared in $2015^{27}$ and $2016 .{ }^{28}$ Recent more detailed presentations are by Zilberstein. ${ }^{29}$

The third new category is a pair of sites in the Zikhron Moshe and Sha'are Moshe neighborhoods of Jerusalem (northwest of Jerusalem's Old City). Their material aspect is imported transport amphoras.

\section{Sivan and Solar's 1982-1983 Excavations at David's Citadel (Bronze Arrowheads)}

The Sivan and Solar excavations were preliminarily published in a nine-page summary. ${ }^{30}$ In that dig, directed by Renee Sivan and Giora Solar in the courtyard of David's Citadel, a fragmentary floor with signs of burning was uncovered. It was located near the bedrock, along the outer face of a wall identified as part of the "First Wall." The excavators described the finds on the floors as "dozens of typical Hellenistic arrowheads ... found together with ballista stones. ${ }^{{ }^{31}}$ A photo of two of the arrowheads stamped with a betaepsilon monogram (E) appears on page 174; Sivan added that four of the arrowheads in the assemblage were stamped. From the heavy deposit of carbonized material, presumably ash, and the finds related to combat (arrowheads, ballista stones) Sivan and Solar concluded that the floor attested to a battle at that place. Moreover, they associated the battle with the siege of Antiochus VII in Jerusalem.

The excavators' claim has largely been accepted. Geva cited the partially exposed floor in support of his conclusion that the Southwestern Hill of ancient Jerusalem was fortified before Sidetes' siege: "If this identification is correct, and no evidence exists that contradicts it, it shows that during the siege [John Hyrcanus ${ }^{32}$ ] had already restored the wall around the south-western hill of Jerusalem." ${ }^{\prime 3}$

Mazis and Wright, in a recent comprehensive analysis of the arrowhead form (identified by them as Baitinger Type IA5) from David's Citadel, and especially of the $\mathbb{E}$ monogram stamps on numerous arrowheads, made their best case for associating the particular E stamped arrowheads with a body of archers serving in the campaigns of the Seleucid

26 Topographically, the GPL site straddles the western edge of the City of David hill and the eastern descent into what was in antiquity the Tyropoeon Valley. The GPL was excavated in 2003 by Eli Shukron, between 2007 and 2016 by Doron Ben-Ami and Yana Tchekhanovets, and since 2017 by Yuval Gadot, Yiftah Shalev, Helena Roth, Nitsan Ben-Melech, Nitzan Shalom and Efrat Bocher. My thanks to Eli Shukron, Doron Ben-Ami and Yana Tchekhanovets for their permission to note the finds from their excavations here.

27 Ben-Ami - Tchekhanovets 2015.

28 Ben-Ami - Tchekhanovets 2016.

29 Zilberstein 2019; forthcoming.

30 Sivan - Solar 2000.

31 Sivan - Solar 2000, 173.

32 Correction of an unfortunate error in the 2018 text (Hillel Geva, pers. comm.).

33 Geva 2018, 43. Geva wrote "restored" because, as noted, the Southwestern Hill was fortified for some time in the Iron Age, although there is no consensus that the Iron Age fortification extended all the way to David's Citadel. 
King Antiochus VII Sidetes. ${ }^{34}$ The authors stressed that Sivan and Solar stated that most of the arrowheads on the floor were marked with the $E_{\text {device. }}{ }^{35}$ They reported that Sivan provided them with a photograph confirming the presence of at least 22 Baitinger IA5 arrowheads, four bearing the $\mathbb{E}$ monogram stamped upon them.

In July 2018 I had the serendipitous opportunity to examine metal finds from Sivan and Solar's excavations, which had just been delivered for accession to the Israel national collection, after being relocated 36 years after their excavation (cited by Mazis and Wright 2018, 215). It is not known whether the material I saw comprised all the metal finds from the excavations. Nevertheless, a preliminary reporting of what I saw, and a qualification of what Mazis and Wright reported, follows.

The metal finds included objects from Sivan and Solar's excavations as a whole, and not only from the one illustrated floor context. From the archaeological information accompanying the objects, the published floor appears to have been excavated in 1982 and was designated L1128, with the objects assigned Registration no. 11680. Although Sivan and Solar's publication noted that most of the 9 Baitinger IA5 arrowheads on the floor had E stamps I was able to identify only 4, and despite the photo of at least 22 Baitinger IA5 arrowheads, what was delivered were 17 Baitinger IA5 (bronze) arrowheads and 8 iron butt spikes (components of spears used on their rear ends as counterbalances).

Three other loci in the dig produced the remaining 5 E-stamped Baitinger IA5 arrowheads, and another one (or more) loci yielded the other 8 unstamped Baitinger IA5 arrowheads. I cannot know for certain how these four or more other contexts were defined, be they floors, fills, accumulations or unstratified, and where they were located. However, some of the objects may nevertheless derive from nearby contexts above or alongside, or otherwise in proximity, with the photographed locus (L1128?) - judging from the locus numbers of those objects (L1126-1127 and 1129-1130). Those four loci yielded 2 Baitinger IA5 arrowheads ( 1 with a $E$ stamp and 1 without), and 6 butt spikes. In addition, a lead sling bullet (with winged thunderbolt decoration) was found in L1129.

The rich assemblage of military equipment examined by me shows that four kinds of weapons were shot or thrown at the David's Citadel fortification, arrows, ballista stones, spears and sling bullets. Arrows shot from wooden bows ${ }^{36}$ were accurate up to 50-60 m, but their effective range extended to at least 160-175 m. Sling bullets could travel longer, ${ }^{37}$ but inaccurately. The effective range of spears was much less than arrows. In all, 38 iron butt spikes were counted by me in the newly delivered metal finds from Sivan and Solar's excavations. Were it not for those objects, one could argue that the fortification wall at the David's Citadel was attacked only from a distance, by arrows, ballista stones, and sling bullets, and there would have been no evidence that the wall was assaulted from close up. The dozens of butt spikes make it much more likely that fighting also took place closer to the wall. That said, the objects cannot indicate whether the fortification at the Citadel was taken.

Much of Mazis and Wright's support for the connection between the stamped arrowheads and Antiochus VII Sidetes is based upon the excavation of such finds in

34 Mazis - Wright 2018.

35 Mazis - Wright 2018, 215.

36 McLeod 1965, 8.

37 McLeod 1965, 14. 
Syria and Israel. At Jebel Khalid in Syria five Baitinger IA5 arrowheads were found, four stamped ${ }^{38}$ in Israel, besides the finds from the David's Citadel courtyard, three

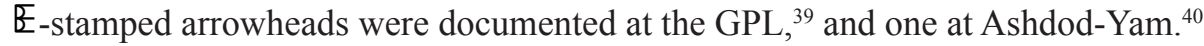

Based upon the evidence of the provenances of the Baitinger IA5 arrowheads ${ }^{41}$ and especially those with $E^{-}$stamps, Mazis and Wright's case for identifying that group of arrowheads with archers fighting in Antiochus VII's army is compelling. This identification, however, leaves some questions unanswered. Was the fortification at the David's Citadel taken? How does this evidence for Antiochus VII's army there accord with the three $\mathbb{E}_{2}$-stamped arrowheads reported from the GPL? At that site as well, there is archaeological evidence supporting a Seleucid assault upon a glacis and tower, part of a contemporaneous fortification system which included a city-wall located there. That wall, as will be shown, enclosed the City of David hill. It may be noted here that Mazis and Wright ${ }^{42}$ cited a personal communication by the excavator at the GPL, Doron Ben-Ami, that "the spatial distribution of the arrowheads [found at the GPL] shows they mostly come from the glacis [of the aforementioned fortification system]."

That is to say, a comparable number of :-stamped Baitinger IA5 arrowheads were found at the courtyard of the David's Citadel and at the GPL, and all were well contextualized to the Seleucid siege.

Unfortunately, the full assemblage of finds of military equipment at the GPL is not yet known. Before turning to the following section on a different category of finds from the GPL site, I will summarize what is known about military equipment from that site.

Ben-Ami reported to Mazis and Wright that some of the arrowheads "originated in later fills." per surface of the glacis." ${ }^{44}$ I understand "later fills" to mean that the arrowheads were residual; i.e., that there were arrowheads in contexts that date after the glacis was out of use. Stiebel, who is charged with the publication of the military equipment at the site, ${ }^{45}$ has already published the military equipment from first (2007) season. ${ }^{46}$ In Stiebel's chapter listing 35 items, he noted as "striking" that although most evidence of military equipment from classical Jerusalem had (until 2012) been found in the Southwestern Hill, most of the projectiles from Jerusalem, including arrowheads as well as light and

38 Mazis - Wright 2018, 213.

39 Mazis - Wright 2018, 215 and note 20; and below.

40 Mazis - Wright 2018, 216. A fourth Israeli find with evidence of combat by Antiochus VII's forces may be from Tel Dor, where "arrowheads, ballista stones, and lead sling bullets" were uncovered, with the assemblage being "almost identical" to the David's Citadel finds (referring to the arrowheads and ballista stones). The lead sling bullets from Tel Dor, not noted at the Citadel by Sivan and Solar, are nonetheless definitively dated to the historically documented siege of Antiochus VII, at that coastal city (1 Macc 15, 13-14, 25; Mazis - Wright 2018, 213). No stamped arrowheads have been reported from Dor. On the subject of sling bullets, incidentally, at David's Citadel, besides the one noted above from the Israel national collection, two more were among the metal artifacts recently accessed from the excavations.

${ }^{41}$ Another unstamped arrowhead of this type was recently reported in 2018, from Horbat Turit, roughly $4 \mathrm{~km}$ east of 'Akko-Ptolemais (Atrash - Mazor - Aboud 2018, 82).

42 Mazis - Wright 2018, 215.

43 Mazis - Wright 2018, 215.

44 Mazis - Wright 2018, 216.

45 Mazis - Wright 2018, 216, note 23.

46 Stiebel 2013, not cited by Mazis - Wright 2018. 
torsion artillery projectiles (see below), were uncovered at the GPL, on the City of David hill. ${ }^{47}$

Stiebel's chapter catalogued one "flat, tanged" arrowhead, ${ }^{48}$ from an Early-Roman period cistern. Although he did not employ Mazis and Wright's Baitinger IA5 classification, he noted that it was a common Hellenistic-period type and may have been a residual find. The other two in Stiebel's catalogue were not of the same type as no. 3, but came from GPL's Hellenistic stratum. ${ }^{49}$ Another relevant find is a lead sling bullet. ${ }^{50}$ This item, found in a drainage channel, was also deemed a residual find. Another lead sling bullet was found, ${ }^{51}$ this one in the Hellenistic stratum, but its shape is not like Stiebel's no. 6, nor the ones I reported from Sivan and Solar's excavations. In sum, based upon the military equipment from the GPL's 2007 season, numerous other Hellenistic-period finds similar to the few Baitinger IA5 arrowheads thus far reported from the fortifications area at the GPL, and from the partially exposed floor exposed by Sivan and Solar, are likely to have been found in Ben-Ami and Tchekhanovets' later seasons. As Ben-Ami already reported to Mazis and Wright, some were in fact found in later contexts. Residual or not, they constitute evidence of an attack on the Hellenistic-period wall on the western side of the City of David Hill.

\section{Ben-Ami and Tchekhanovets' Excavations at the Giv'ati Parking Lot (coins) ${ }^{52}$}

In the 2011-2015 excavation seasons at the GPL a fortification system was uncovered. ${ }^{53}$

The fortification system is comprised of a $3.4 \mathrm{~m}$ wide north-south wall preserved to a maximum height of $3.7 \mathrm{~m}$, against which a $4 \mathrm{~m}$ wide tower was added, and alongside the tower, two distinct glacis elements were poured. Zilberstein (2019, 37-40) has determined that the north-south fortification line, roughly $24 \mathrm{~m}$ in length, was a city-wall. The two glacis elements were poured along the outer (western) face of the tower above earlier remains. They are two massive inclined fill layers, each laid down in different directions. The lower glacis is composed of gravel, while the upper glacis is defined by its overwhelming composition of broken pottery. The dating of the ceramics found in both layers is indistinguishable, providing general second half of second century BC dates. As for the coins found in the two elements, small numbers were found in the lower, "gravel glacis." The latest coin found is an issue of Demetrius I (162-150 BC) and Zilberstein thus dated that glacis to the third quarter of the second century BC. The coins found in

47 Stiebel 2013, 297.

48 Stiebel 2013, 297, no. 3.

49 Stiebel 2013, 297, no. 3.

50 Stiebel's $(2013,299$, no. 6) term: biconical leaden pellet.

51 Stiebel 2013, 299, no. 7.

52 I was entrusted with the identification and publication of the coins from these excavations by Doron Ben-Ami and Yana Tchekhanovets, and am grateful to them for their discussions with me about the coins' meaning.

53 See Zilberstein, forthcoming. The fortifications of the GPL are the subject of Ayala Zilberstein's doctoral research. I am grateful to her for discussing the stratigraphy of the fortification system with me, and for reading an earlier version of this paper. I am not relating here to further soundings into elements of the fortification system undertaken by the Shalev-Gadot team (note 26) now excavating at the site. 
the upper, "pottery glacis" have a completely different profile. Early coins similar in profile to those in the lower, gravel glacis were present but, in addition, there were tens of $\operatorname{coins}^{54}$ of Antiochus VII found there. Most of the types were local, Jerusalem-minted issues that date to $132 / 131-131 / 130 \mathrm{BC}^{55}$

The chronological distinction between the lower, gravel glacis, and the upper, pottery glacis is indisputable. While the terminus post quem date supplied by the Demetrius I coin in the lower, gravel glacis can suggest a number of historical reconstructions for the pouring of the glacis, the upper, pottery glacis must be dated after $131 \mathrm{BC}$; i.e., after Sidetes' siege of Jerusalem. In other words, for our question about the date of the western city-wall around the City of David hill in the Hellenistic Period, for which there has been no consensus, the numismatic evidence from the GPL fortification system clearly indicates that the later city-wall encircling the City of David hill itself was renovated not before $131 \mathrm{BC}$, with the addition of the higher glacis element.

It should be noted that Zilberstein also analyzed the published architectural remains of the structures uncovered in excavations by John Winter Crowfoot and George M. Fitzgerald in 1927 several dozen meters south of the GPL fortifications. She found that they have strong architectural parallels with the newly excavated fortifications to the north, including sloping layers to the west of a massive ashlar wall, which Zilberstein concluded was the continuation of the GPL fortification line.

Coins remain in circulation for many years after they are first issued. From the coin evidence thus far presented, one cannot know a reasonable end date for the pouring of the upper, pottery glacis at the GPL. However, it is also possible to determine a terminus ante quem date for the pouring of that glacis. Zilberstein (forthcoming) indicated that there is a total absence from both glacis systems of coins associated with autonomous (Hasmonean) coin issues later than 132/131-131/130 BC. The first coins of the Hasmonean series were issued by John Hyrcanus I (Ariel, forthcoming). The most recent estimation, in the aforementioned forthcoming article, of the date of Hyrcanus' first coin series is $c .125-123 / 122 \mathrm{BC}$. However, Hyrcanus' first coin series is extremely rare. The same forthcoming article suggests a reasonable date for the later coin issues of that high priest as being close to the end of his period of rule, i.e., less than a decade before Hyrcanus' death in $105 \mathrm{BC}$. This means that the timeframe that the coins in the two glacis provide for the date of the upper, pottery glacis is between 131 and $105 \mathrm{BC}$. In other words, High Priest John Hyrcanus I was responsible for the pouring of the upper, pottery glacis. Historically, this means that although, after Antiochus VII's death in 129 BC,,$^{56}$ the high priest was more secure in his rule of Judea than any of his Hasmonean ancestors, he still thought it prudent to maintain the fortification line on the western side of the City of David hill, the old city-wall.

It might be added that Zilberstein $(2019,39)$ stated that the lower, gravel glacis was more strongly constructed than the later, pottery glacis, but that the latter, less solid, was

54 Mazis - Wright (2018, 215 note 21) cited me noting "at least 120" coins of Antiochus VII found in the upper, pottery glacis, in a webinar contribution to The Maccabees Project in 2016. With Ayala Zilberstein's clarification of the stratigraphy of the upper, pottery glacis, numbers of these coins have been relegated to less certain contexts. The overall chronological framework, however, still stands.

55 Zilberstein, forthcoming; for a numismatic discussion. See Ariel 2019, 43.

56 Or, perhaps, the very beginning of 128 BC. See Ariel 2019, 51 note 16. 
nevertheless unquestionably a glacis. Moreover, she explained that a repair to the upper courses of the tower appended to the city-wall was found in the excavations. It is thus possible to relate to the less robust pottery glacis and the tower repair as contemporary and view both as hasty efforts by Hyrcanus to reinforce the western city-wall around the City of David Hill.

According to Zilberstein $(2019,40)$, above the upper, pottery glacis and with no intervening layers, clear indications were found for the collapse of the tower appending the fortification line. Zilberstein viewed the collapse as the result of laborious dismantlement operations. Moreover, she described the layer above it as a large undertaking to level the area for new construction. The ceramic profile in the layer of leveling work, as well as coins of the Hasmonean series and some contemporary non-Hasmonean coins, brought Zilberstein to the conclusion that the leveling project dated to the end of the second-beginning of the first century BC.

Before turning our attention to the third assemblage of finds, it may be helpful to return to the lower, gravel glacis at the GPL and unpack its significance. Thus far, all that was said here about the lower, gravel glacis was that its terminus post quem date (the reign of Demetrius I) can suggest a number historical reconstructions. What are these possible reconstructions?

One possibility is that the lower, gravel glacis served as a revetment to the Akra, if the fortification system at the GPL is to be identified as such. The date of Demetrius I certainly suits such a reconstruction, if part of the Akra was located in the GPL, as suggested by Ben-Ami and Tchekhanovets. ${ }^{57}$

A second possibility for interpreting the lower, gravel glacis would be that Simon Thassi initiated the pouring of the glacis. 1 Macc's account of that high priest's tenure states, contra Jos. AJ 13.217, that Simon did not demolish the Akra, but rather repurposed the structure for his own aims (13.52: he "strengthened the fortifications of the temple hill alongside the citadel, and he and his men lived there."). This idea accords with Geva's assumption that no Jewish ruler would have been in a position to fortify the city-wall while the Greek garrison remained in the Akra $(2018,44)$.

It should be noted that, after $141 \mathrm{BC}$, it is immaterial whether the credit for pouring the lower, gravel glacis should go to Simon Thassi or John Hyrcanus, as in any case the latter was Simon's army chief, and he may have been the one to reinforce the city-wall by adding the glacis, either while his father was alive or after his death.

When one adds the presence of Baitinger Type IA5 arrowheads at the GPL, and particularly the three with $E$ monograms stamped on them, it becomes reasonable, if not likely, to conclude the fortification system was functioning during the siege. This supports my supposition that the lower, gravel glacis functioned as one of the elements defending Jerusalem from attack by Antiochus VII Sidetes-because the upper, pottery glacis is not a candidate. Recalling that the latest coin from that glacis was issued by Demetrius I, we may add that, in Jerusalem, few Seleucid coins are found after Simon ejected the Seleucid garrison from the Akra (see Table 2 below), so it is difficult to know from the coins found in the lower, gravel glacis whether it was poured during Simon's rule or John Hyrcanus' tenure. Because the numbers of coins found in that glacis is small,

57 Ben-Ami - Tchekhanovets 2015, 321-322. 
and there is no evidence of an intervening layer between it and the upper, pottery glacis with its clear end-of-130s BC date, the lower, gravel glacis and the $\mathbb{E}$-stamped arrowheads, seem to provide strong evidence for Sidetes' siege at the GPL.

\section{Pair of sites in the Zikhron Moshe and Sha'are Moshe neighborhoods of Jerusa- lem (imported transport amphoras)}

The subspecialty of Hellenistic imported transport amphoras, and the sub-subspecialty of their stamped handles have made important contributions to archaeological and chronological questions about Jerusalem. ${ }^{58}$ In the context of the initial occupation and ultimate fortification of Jerusalem's Southwestern Hill, the distribution of fragments of transport amphoras was discussed by $\mathrm{me}^{59}$ and subsequently by Finkielsztejn.

The low incidence of finds of transport amphora fragments in the Southwestern Hill supported the decades-long and still current consensus that the Southwestern Hill was sparsely occupied in much of the second century BC, and that settlement there grew gradually. Somewhat more recently, a focus on some amphora fragments found in the Southwestern Hill dating later than the chronological peak of imported amphoras in Jerusalem - the mid-second century BC — has highlighted these finds' contribution to understanding the pace of the growth of settlement there. ${ }^{60}$ Most recently, Finkielsztejn (forthcoming) discussed the only stamped Nikandros group handle found in Jerusalem, found in the Jewish Quarter and originally published by me.$^{61} \mathrm{He}$ noted that it dated to the very end of the second-first century $\mathrm{BC}$, and that it joins other evidence for a resurgence of imports in Jerusalem only in the late second century BC (Finkielsztejn's emphasis).

A new datum point relating amphora finds to our question of the settlement and ultimate fortification of the Southwestern Hill of Jerusalem was found in two short salvage excavations in the adjacent Zikhron Moshe and Sha 'are Moshe neighborhoods of Jerusalem. In 2006 a Rhodian "top-of-jar" amphora and another unattached Rhodian stamped handle were found in a salvage excavation on Hayei Adam Street (near its junction with Strauss Street) in the Sha'are Moshe neighborhood. ${ }^{62}$ The amphora material was found

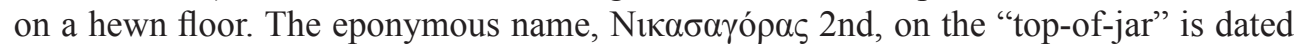
by Finkielsztejn to $c$. 133/132 BC.

Some $175 \mathrm{~m}$ west of that site, in 2017, an ancient ceramic refuse dump at 13 Yesha'yahu Street in the Zikhron Moshe neighborhood yielded a large number of indicative amphora fragments, including dozens of Rhodian stamped handles. The excavations yielded a quite restricted range of dates towards the end of the second third of

58 E.g., Ariel 1990, 13-98; Ariel 2000; Ariel 2003; Ariel 2004; Ariel 2013; Ariel 2015; Ariel, forthcoming b; Finkielsztejn 1999; Finkielsztejn 2006; Finkielsztejn 2008; Finkielsztejn 2014; Finkielsztejn, forthcoming.

${ }_{59}$ Ariel 1990, 21-25; Ariel 2000, 267-268.

${ }^{60}$ Finkielsztejn 2001, 172, note 36.

${ }^{61}$ Ariel 2000, 274, no. 31.

62 Landes-Nagar 2009. 
the second century BC, and one coin issued by Antiochus VII. ${ }^{63}$ The latest dated Rhodian stamp has the same name - and date - as the "top-of-jar" from the Hayei Adam Street site. ${ }^{64}$ These two assemblages strongly suggest that some encampment related to Antiochus VII's siege forces was located nearby, and that the siege probably dated to $c .133 / 132 \mathrm{BC}$.

The Hayei Adam Street and the 13 Yesha'yahu Street sites are 1,350 and 1,500 m, respectively, northwest of the fragmentary floor with evidence of fighting and fire in the courtyard of David's Citadel - and 2,000 and 2,150 m from the glacis of the GPL. Those distant sites, and the presumed Seleucid military installation that is likely to have been in its proximity, would have been well out of range of projectile attack from the Jewish defenders of Jerusalem, and not a long distance for Seleucid forces to march to the battleground - if the presumed installation in fact quartered combat troops. ${ }^{65}$

\section{Discussion}

An impediment to the elucidation of some of the chronological issues surrounding the occupation of the Southwestern Hill, and the GPL site, has been the poor use of dates in publications. From the above discussion it should be clear that earlier dating the fortification of the Southwestern Hill merely to the second half the second century BC is too broad and could (and has) engendered confusion. Datings defined as "before" or "after" the key Seleucid siege would have been more helpful.

Regarding the GPL site, when Ben-Ami and Tchekhanovets ${ }^{66}$ cited the coins at the top of the glacis (later, the "upper glacis") as dating to "Antiochus VII (138-129 BC)," when in fact the dates of the coins were reported to them as primarily 132/131-131/130 $\mathrm{BC}$, this unfortunately did not allow the reader to understand a key chronological point, that the upper glacis was poured after the siege ended. Similar misleading datings appeared in Zilberstein's Hebrew summary (2019) and will be corrected in the English version.

63 The site was excavated by Kfir Arviv and Alexander Wiegmann. Gérald Finkielsztejn is principal investigator of the imported amphora material. I am grateful to all three for their permission to note the relevance of the amphora material for the research question here. The coin was identified by me.

${ }^{64}$ Finkielsztejn's indefinite identification of the unattached Rhodian stamped handle from the Hayei

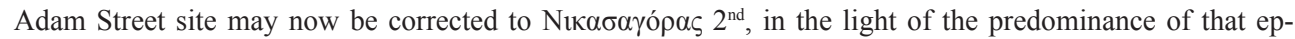
onym at the 13 Yesha'yahu Street site. Hence, both eponym stamps at the Hayei Adam Street site name

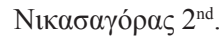

65 Yet another stamped Rhodian amphora handle was found at a third excavation, at a site on Sonnenfeld Street, in the Ge'ula neighborhood of Jerusalem: Finkielsztejn 2008. The site is between 475 and $600 \mathrm{~m}$ northeast of the pair of sites in the Zikhron Moshe-Sha'are Moshe neighborhoods and a similar distance to David's Citadel as the pair of sites are. The Sonnenfeld Street stamped handle's date is perhaps a year before the latest dated stamp at the other two sites.

Another stamped handle, found at Kikkar Safra (City Hall; less than $600 \mathrm{~m}$ from David's Citadel) is Koan: Ariel 2004, 183, Fig. 14:2. It dates to the later part of the second century BC. Other stamped handles with the same name (and date) as the one from Kikkar Safra were found in Jerusalem: one in the Jerusalem Citadel (unpublished, from Sivan and Solar's excavations), one in the Jewish Quarter (Ariel 2000, 274, no. 29), and two in the City of David (Ariel 1990, 75, S459-460).

${ }_{66}$ Ben-Ami - Tchekhanovets $(2015,318)$. 
Another point worth stressing is the role of Hyrcanus' city-wall (re)building in the dating of $1 \mathrm{Macc}$. The verse in which the author of 1 Macc noted Hyrcanus' (re) building of city-wall is key to the dating of the treatise to the rule of that high priest. There is no reportage of Antiochus VII's Jerusalem siege in 1 Macc. Yet the achievements attributed to John Hyrcanus after the death of his father Simon, "his wars and the brave deeds that he did...written in the annals of his high priesthood" (vs. 23-24) explicitly included the city-wall that he (re)built. This inclusion, matching the trope of wall-building his father and two protagonist uncles shared, together with the fact that Hyrcanus' death is not mentioned in 1 Macc, plays a role in Bar-Kochva's determination ${ }^{67}$ that $1 \mathrm{Macc}$ was written not long after $129 \mathrm{BC} .{ }^{68}$ Bar-Kochva argued that city-wall building would logically have been one of the first things that Hyrcanus undertook after the death of Sidetes in 129 (early 128?) BC. Bar-Kochva further argued that Hyrcanus' (re)construction of Jerusalem's fortifications would probably not have been highlighted in such a way if the author of 1 Macc had been aware of the great changes in political conditions that the high priest witnessed and his own successes at territorial expansion in the course of his rule ${ }^{69}$ Therefore, the archaeological evidence of the upper, pottery glacis with coins dating until 131/130 BC supports the cogency of Bar-Kochva's contention that Hyrcanus fortified Jerusalem soon after Sidetes' death.

It is this contention that argues for preferring an early date for the pouring of the upper, pottery glacis, rather than the broader 131-105 BC date I cited above.

\section{Written sources}

The Josephus' account of Antiochus VII's siege of Jerusalem in AJ 13.236-252 must now be considered. Bar-Kochva's most recent analysis of the subject (2010) is quite innovative, carefully argued and largely compelling. I will explain the scholar's conclusions and point to aspects that, in my view, are not in accord with the newest archaeological discoveries raised above. The interweaving of Nicolaus of Damascus' account (the "short siege story" in $B J$ ) into a longer account Josephus found in Strabo's writings (the "long siege story") engendered the Antiquities siege narrative. Bar-Kochva determined that Strabo source for the "long siege story" was Posidonius of Apamea, and that Posidonius adapted reporting by Timochares. Partially by looking at a fragment of Timochares' description of the geography of Jerusalem preserved by Eusebius, and partially through Bar-Kochva's analysis of Posidonius tendentious writing, the historian acknowledged that large portions of Josephus' account was "imaginary and tendentious," due to Posidonius' ${ }^{70}$ changes to Timochares' text, ${ }^{71}$ and that Posidonius had made "well-calculated

67 Bar-Kochva 1996, 277.

68 Or, Bar-Kochva 1989, 163: between 129 and 126 BC.

69 Bar-Kochva $(1989,163)$ also explained the "unusual reference to a chronicle which had not yet been completed" as a literary device to resolve the fact that the narrative of Hyrcanus' reign in the book was cut short.

70 And possibly Strabo: Bar-Kochva 2010, 416.

71 Bar-Kochva 2010, 458. 
additions, omissions, and alterations." ${ }^{\prime 2}$ The scholar nevertheless identified what he saw as the "kernel of historical truth" in the transmitted text.

As regards the siege itself, Bar-Kochva pointed to "extreme exaggeration with regard to military installations and constructions." ${ }^{.73} \mathrm{He}$ rejected the description of the erection of "a hundred towers, each three stories high, on which [Antiochus] mounted companies of soldiers" along the northern wall (Jos. $A J$ 13.238). However, despite the fact that Timochares' fragment in Eusebius describes Jerusalem as being "hard to take, being shut in on all sides by precipitous ravines, "'74 Bar-Kochva accepted as true the Josephus' ( $A J$ 13.238) account of "the north side of the wall, where the ground happened to be level." The fortification line called the "First Wall" (introduced above), in fact, is consensually restored as having long northern stretches which are level-relative to the remainder of that wall line that overlooks precipitous ravines. ${ }^{75}$ In general, the historian was willing to accept the Josephus' account of the topography of Jerusalem, because it fit Posidonius' tendentious interest in presenting a favorable view of Jerusalem as the city in which Moses chose to settle ${ }^{76}$ - and possibly also because he knew that most attacks on Jerusalem have begun from the north, ${ }^{77}$ and that the archaeological consensus is that the "First Wall" was standing during Sidetes' siege. ${ }^{78}$

Timochares' Eusebian fragment does not note any ground that happened to be level along any of the perimeter wall of Jerusalem. Bar-Kochva viewed this discrepancy between the Eusebian fragment and Josephus' account as "not significant." Timochares, who wrote the fragment, may or may not have made any error. If he was an eye-witness to the siege, as Bar-Kochva hinted,$^{80}$ and he knew of no northern wall, then perhaps there was no northern wall. Or, maybe the fortification around the City of David hill and the Temple Mount, was all Timochares saw. ${ }^{81}$

Josephus, on the other hand, would certainly have known of the northern stretch of the "First Wall," and was capable of "correcting" the Posidonius-Strabo account, which possibly cited no northern wall..$^{82}$ If the Jewish historian added the northern wall to the text, he may also have revised the location of Posidonius' exaggerated hundred towers, which included the story of the misfortunate Jewish fighters caught between the Seleucid besiegers and an unsympathetic Hyrcanus. ${ }^{83}$

72 "Peculiarities" of the Josephus' account of the siege attributed by Bar-Kochva to Posidonius are summarized in his 2010 volume on pp. 421-422.

73 Bar-Kochva 2010, 421; see also p. 468.

74 Bar-Kochva 2010, 258 (emphasis mine).

75 Bar-Kochva 2010, 460; see his map on p. 419 and see also Geva 2018, 42.

76 Bar-Kochva 2010, 463.

77 Bar-Kochva 2010, 433

78 Bar-Kochva $(2010,434)$ cited Sivan and Solar's arrowheads and artillery stones at the Citadel excavations in support his idea that the military efforts were focused on the north wall.

79 Bar-Kochva 2010, 460.

80 Bar-Kochva 2010, 466.

81 Of course, as it is now agreed, the "First Wall" did exist at that time. Yet another possibility is that Timochares was not an eye-witness to the siege, but, instead, he relied on someone else's anachronistic description of Jerusalem before the wall's construction.

82 See Britt - Boustan 2017, 68.

83 Bar-Kochva $(2010,417)$ raised the possibility that it was Josephus who made a connection between the Timochares-Posidonius' seven-day cease fire with the Feast of Tabernacles. 
It is reasonable that the acknowledged heavily redacted text of Antiochus' siege of Jerusalem in Josephus' Antiquities should be discounted as support for the presence of a northern fortification line, and consequently the construction of the "First Wall" by that time. The shorter fortification line around the City of David hill and reaching up to the Temple Mount could have been the city-wall besieged by Antiochus VII. Josephus, the historian who, in Antiquities 5, first described the "First Wall" as it stood in 66 AD, and knew that in $70 \mathrm{AD}$ the city would be breached by Titus' army from the north, is likely to have assumed that Antiochus VII did the same in the late 130s BC, and thus possibly made a "correction" to the "long siege story," despite Bar-Kochva's understanding of that text.

In sum, the written sources have not produced a compelling contribution to determining Jerusalem's fortifications before Sidetes' siege, owing to the uncertainty in establishing the reliability of the text on the question of the northern wall.

\section{Numismatics $^{84}$}

The diffusion of second-century BC coins in the Jewish / Armenian Quarters and Mount Zion may provide evidence of the pace at which the Southwestern Hill was occupied. I begin with the distribution of the coins of Antiochus VII alone. Table 1 presents the provenanced Antiochus VII coins in Jerusalem, according to types.

The 16 Antiochus VII coins coming from David's Citadel are all of the 132/131131/130 Jerusalem-mint types. Their relatively high numbers cannot be explained by the siege that supposedly took place there, because these coins date from after the siege only. The quantities must relate to the intensive excavations carried out there, especially between 1933 and 1938, and possibly from the sites continued military importance after the $132 \mathrm{BC}$ siege, again, assuming a Seleucid attack there. The 16 coins cannot be used to determine when the hill as a whole was densely populated. Because only 12 Antiochus VII coins come from elsewhere on the Southwestern Hill (2 on Mount Zion, 7 in the Jewish Quarter and 3 in the Armenian Garden), Table 1 would suggest that the Southwestern Hill was sparsely occupied until the end of the second century BC. Such a conclusion contrasts significantly the impression from the previously reported evidence from the Southwestern Hill. The results of Table 1, however, accords with the evidence presented above of a resurgence of imports in Jerusalem only in the late second century BC.

The data was collected until the end of the first century BC, for comparison purposes. The key conclusion from Table 2 is an obvious one. Third- and second-century coins found in the City of David hill are proportionately more common than those found on the Southwestern Hill. The degree that this is true may be expressed by the figure that coins before the 132/131 BC inauguration of the Jerusalem mint are 3.7 times more common in the City of David than those in the Southwestern Hill. This is not to say that there is a connection between the beginning of the Jerusalem mint and the settlement of the Southwestern Hill. The results of my analysis of the data were virtually the same when

${ }^{84}$ Unless otherwise noted, the coins amassed on Tables 1 and 2 are drawn from the Israel national collection, administered by the Israel Antiquities Authority. 
the cutoff was set at the middle of the second century BC (the coins of Demetrius I) and even when the comparison was made when coins dating through the rule of Aristobulus $(105 / 104)$ were included. It merely confirms that the other indications in the material culture of the Southwestern Hill are correct that Southwestern Hill was settled much later than the City of David.

Table 1. Provenanced Antiochus VII coins in Jerusalem

\begin{tabular}{|c|c|c|c|c|c|}
\hline \multirow[t]{3}{*}{ Site(s) } & \multicolumn{4}{|c|}{$\begin{array}{l}\text { Antiochus VII } \\
\text { mint }\end{array}$} & \multirow[t]{2}{*}{ Notes } \\
\hline & \multicolumn{3}{|c|}{ Now, Jerusalem } & Antioch & \\
\hline & $\begin{array}{l}\text { lily/anchor } \\
\text { (No. 2123) }\end{array}$ & $\begin{array}{l}\text { helmet/ } \\
\text { aphlaston } \\
(\text { No. 2122) }\end{array}$ & $\begin{array}{l}(S C 2123 \\
\& S C 2122)\end{array}$ & $\begin{array}{l}S C 2068 \\
\& \text { SC } 2072\end{array}$ & \\
\hline City of David & 128 & 15 & 143 & $\begin{array}{c}6 \\
\text { (4 from GPL; } \\
1 \text { of these: } \\
\text { "imitation of } \\
\text { Antioch") }\end{array}$ & \\
\hline Mount Zion & 2 & - & 2 & - & \\
\hline $\begin{array}{l}\text { Ancient Jerusalem (= within } \\
\text { Ottoman walls, and without } \\
\text { City of David \& Mount Zion) }\end{array}$ & 40 & - & 40 & 1 & $\begin{array}{l}\text { [includes } \\
\text { David's } \\
\text { Citadel] }\end{array}$ \\
\hline [David's Citadel & 16 & - & 16 & - & $\begin{array}{c}\text { part of } \\
\text { above row] }\end{array}$ \\
\hline $\begin{array}{l}\text { All ancient Jerusalem (City of } \\
\text { David, within Ottoman walls } \\
\& \text { Mount Zion) }\end{array}$ & 170 & 15 & 185 & & \\
\hline $\begin{array}{l}\text { Modern municipal limits of } \\
\text { Jerusalem only (without an- } \\
\text { cient Jerusalem) }\end{array}$ & 13 & 4 & 17 & 5 & \\
\hline All Jerusalem & 183 & 19 & 202 & 12 & \\
\hline
\end{tabular}

The coin percentages were also examined from another perspective. Considering the percentages of coins until the end of the first century BC, we found that proportionately more later coins were found in the Southwestern Hill than in the City of David. In other words, discounting the early coins, the relative numbers of coins from City of David hill, even from the middle of the second century, were smaller than those found in the Southwestern Hill. Taking the percentages from those 150 years, coin finds in the Southwestern Hill were $30 \%$ higher than those in the City of David. There obviously was a time when equilibrium between the relative quantities in the City of David and Southwestern Hill was reached, but I cannot determine that point, because there were always earlier coins in circulation and one cannot easily correct for that. 
In sum, it was hoped that, using the City of David coin finds as a base line, the coin distributions from the Southwestern Hill as a whole would point to a date after which settlement there began to grow significantly. Such a date was not found in the data on Table 2 .

A look at the relationship of the numbers of coins found according to the separate settlement areas in the Southwestern Hill indicates that the Mount Zion, Armenian Garden and David's Citadel sectors, respectively, yielded more pre-Jerusalem mint Hellenistic coins than from the Jewish Quarter. Could this be numismatic evidence for an early date in the second century $\mathrm{BC}$ for the construction of the wall, which preceded, to some degree, settlement in the center of the hill? ${ }^{85}$

\section{Imported Transport Amphoras}

Let us now turn to the archaeological evidence of the pair of sites containing imported amphora material in the Zikhron Moshe and Sha'are Moshe neighborhoods of Jerusalem, and the other two excavations with stamped handles in that northwestern direction (note 65). The pair of sites are 1,350/1,500 m northwest of the Citadel or a full 1,700 m from the closest segment of the City of David fortification wall (at the northeast corner of the Temple Mount; see Fig. 1).

Considering the likely location of a Seleucid camp near those sites, it would clearly make more sense were the camp closer to the combat zone - even if it was only a "rear camp," for storing provisions. Of course, factoring the distance of the pair of sites to David's Citadel ignores the great probability that there were a number of other Seleucid camps surrounding Jerusalem. Josephus' account mentions seven camps, but that number is no longer considered historically reliable. It is, however, most likely that a second, or a third, camp would have been placed further to the east, assuming the "First Wall" was already constructed and combat was focused on the northern wall. ${ }^{86}$

Nevertheless, the amphora-related sites northwest of ancient Jerusalem supports the construction of the "First Wall" before Sidetes' siege. ${ }^{87}$

85 Careful examination suggests two anomalous figures appear on Table 2. The first is the extremely high numbers (839) of Jannaeus imitations (TJC:210, Subgroups L7-14) in the Jewish Quarter. This anomaly is clearly due to at least 677 of these coins in Area E (Ariel 2006, 193 ["disproportionate quantities of Jannaeus coins ... particularly unusual"] and 205-208, nos. 50-226). The second anomaly is the high number (18) of coins of Hyrcanus I at the Armenian Garden (all from the 1961-1967 excavations; Lawrenz 1985,159), suggesting to me that the identifier of those coins (Lawrenz) had an identification bias towards Hyrcanus I.

86 It is important to remember that one cannot compare the possibility of one Seleucid camp located approximately at Jerusalem's Zikhron Moshe-Sha'are Moshe neighborhoods with the array of camps that Herod and Sosius built to besiege Jerusalem in 37 BC. At that later time, the first city-wall that needed to be breached was the "Second Wall," north of the "First Wall." One also cannot compare the location of a site such as that at Yesha'yahu and Hayei Adam Streets to Titus' preparations for the Roman assault of the city, which first began with a breach of the "Third Wall," even further to the north, before the "Second Wall" was overrun. At the time of Antiochus VII's siege the "Second" and "Third" walls had not yet been built.

87 Despite the distance from the city of the amphora finds relating to the siege, it appears that that, after Sidetes' siege, some of those amphoras later made their way into Jerusalem along the 13 Yesha'yahu StreetHayei Adam Street-Kikkar Safra-David's Citadel-City of David axis (see Finkielsztejn 2001, 172, note 36, 172 note 36 for a listing of "late," "Hasmonean-period" stamped amphora stamps at the City of David and elsewhere). 


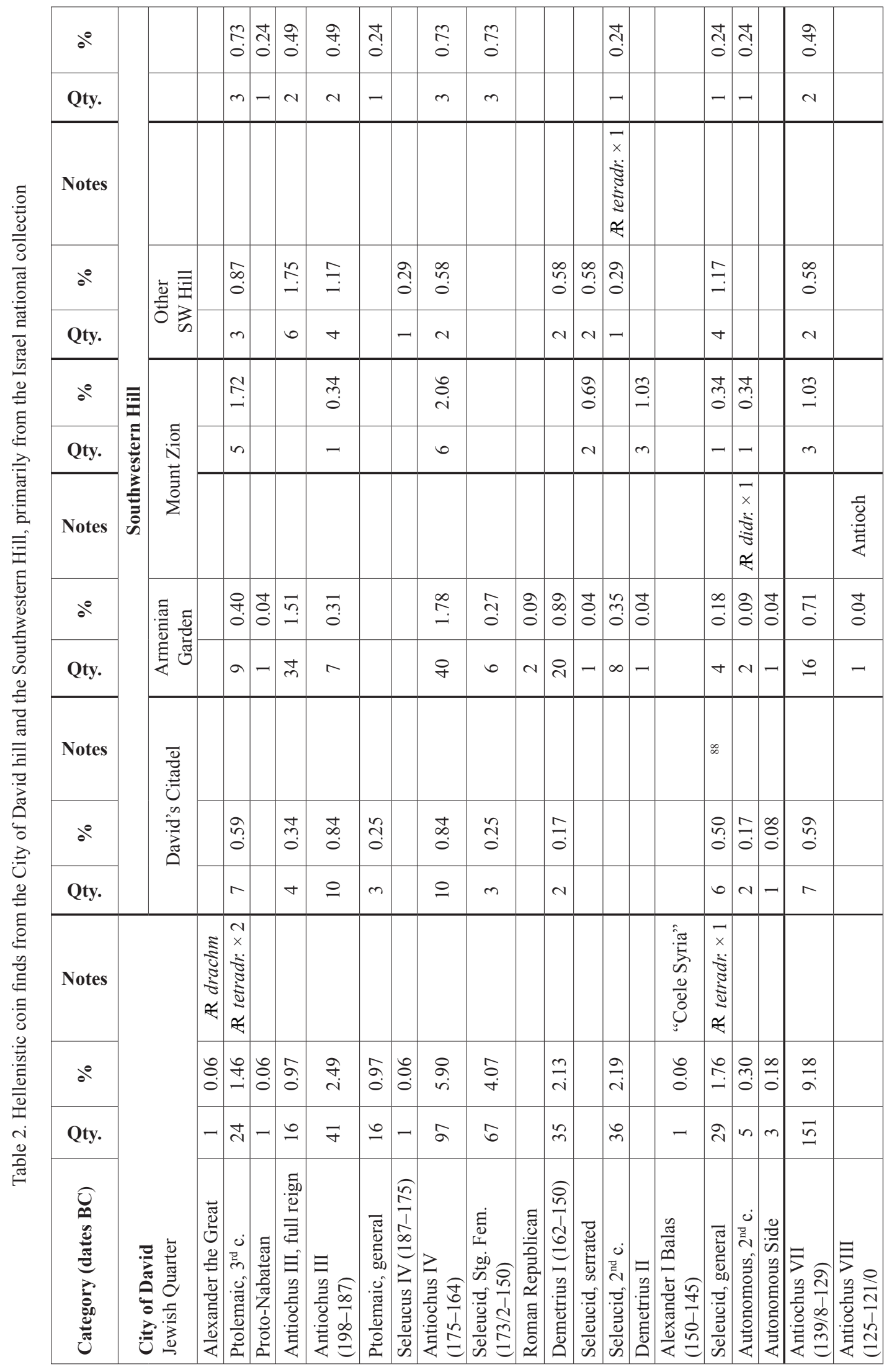




\section{Multiple Coexistent City-Wall Defenses in Jerusalem}

Despite some new doubts about the reliability of Josephus' "long siege story," the new archaeological evidence points to the conclusion that, at the time of Antiochus VII's siege of Jerusalem, one fortification line had already enclosed the city with its newest neighborhood on the Southwestern Hill. Its route followed the ancient mid-slope line on the eastern side of the City of David hill. It then continued around Mount Zion, and north to the David's Citadel area, and ultimately turned east to the Temple, which was also included within the city.

At the same time, the western fortification line of the City of David hill, which had protected the hill during the centuries when that hill comprised the entire city of Jerusalem, was standing. The excavation of two superimposed glacis added to a tower connected to a city-wall suggests that the lower, gravel glacis is likely to have seen battle from an assault by Sidetes' forces. Later, after 131 BC, a second pottery glacis was poured on top of the lower glacis. The many coins found in that glacis establish that it was part of fortification work undertaken by High Priest Hyrcanus I after his vassalage to Antiochus VII had ended with the Seleucid king's death. This dating also accords with Bar-Kochva's analysis of the date of composition of $1 \mathrm{Macc}$ - and his preference for Hyrcanus' wall repairs early in his tenure.

The western fortification line also shared the "First Wall" line along the eastern side of the City of David hill. This was the early wall of Jerusalem and although it was damaged a number of times in the second century BC, by 133/132 BC, it had been restored, and served to defend the ancient quarter of the city against Seleucid attacks. Hyrcanus' defenders apparently held out there until the Feast of Tabernacles, 132 BC (Ariel 2019, 48), when a temporary cease fire was enacted and then extended, followed by negotiations, which ultimately lead to a settlement.

This reconstruction of the events of Sidetes' siege of Jerusalem, from the Jewish defenders' viewpoint, is the most reasonable interpretation of the evidence brought in this paper. There remains to examine the logic behind multiple coexistent city-walls in Jerusalem.

The original nucleus of Jerusalem, the City of David hill, was blessed with naturally defenses. Its precipitous surrounding ravines protected the central portion of the hill from attack. Its water source, the Gihon spring, was below the height where dwellings were easily built and maintained. An early way to protect the water source was to build a dedicated wall around the spring, and thus include the spring within the protected urban area. As the population of the city grew, naturally or by the influx of newcomers or refugees, crowding would have developed and even become commonplace. Already in the eighth century $\mathrm{BC}$, new extramural neighborhoods grew below the eastern city wall. Additional city-walls were constructed, below the main city-wall to protect the extramural neighborhoods (Introduction). At the end of the eighth century, the Gihon spring was diverted to a place that could be safely protected within the city as it was expanding, and ultimately became fortified to the south and west. ${ }^{89}$ It is not known whether the western line of fortification around the City of David hill was maintained at this time, but it may

89 Geva 2018, 30. 
be assumed that after the destruction of Jerusalem in the early seventh century BC, the city returned to its previous small size on the City of David hill. ${ }^{90}$ If fortification was needed around the hill it would have taken the same route as before the original late Iron Age expansion to the west. The presence of a fortified wall segment found at the GPL may be interpreted as evidence that by sometime in the second century $\mathrm{BC}$, after the assault of Antiochus III only on the citadel of the city (note 3), Jerusalem was fortified with a wall.

With the extramural settlement that grew on the Southwestern Hill in the second century, there would have been interest on the part of the residents that their neighborhoods would also be fortified. The small patch of floor in the courtyard of David's Citadel, with its arrowheads, ballista stones, sling bullets and spear fragments, constitutes the best hard evidence to suggest that that this took place before the siege of Antiochus VII on the city in the late 130s BC. Once the "First Wall" was built around the Southwestern Hill, its west-to-east northern segment immediately became the weak link in Hellenistic Jerusalem's fortifications.

Josephus' exaggerated narrative of the Sidetan siege, with its seven Seleucid camps and 100 towers built alongside the north city-wall, may now be rejected. Nevertheless, it is important to note that much literary evidence exists that besieging armies, in the first century $\mathrm{BC}$ and first century $\mathrm{AD}$, focused their attention on the north or northwest of ancient Jerusalem. Most attacks on ancient Jerusalem were mounted from the north, the most advantageous place from which to assault the city. The "Camp of the Assyrians," cited by Josephus twice (BJ 5.303; 504) was located by Ussishkin ${ }^{91}$ in the vicinity of the Russian Compound (or Kikkar Safra-City Hall). ${ }^{92}$ Among a number of arguments in support of Ussishkin's effective agreement with Josephus' identification of that location as the place of the actual Assyrian siege camp of $701 \mathrm{BC}^{93}$ is its relative higher terrain- $30 \mathrm{~m}$ above the highest point in the Southwestern Hill. After Ussishkin's article, in 2015, Dąbrowa, produced a large amount of additional archaeological information, and knowledge of Roman military practice, to locate the "Camp of the Assyrians" (later Titus' camp), at another point not far from Ussishkin's placement, in "the valley contained approximately within today's streets Shivtei Yisra'el and Derekh Shkhem (the Nablus Road)."

In the course of the Hellenistic and Roman sieges of ancient Jerusalem described by Josephus, the historian described multiple wall lines that had to be assaulted and taken, one by one, in order to complete the conquest of the city. During the sieges of Jerusalem by Pompey (64 BC (Jos. BJ 1.141-149), Herod (Jos. AJ 14.470-481) and Titus (BJ 5-6), these fortifications consisted of external and internal city-walls, and the fortified TempleMount temenos.

For the besieging armies, besides the external city-walls, "internal" walls were additional barriers to their progress. Consequently, one may assume that Hyrcanus reinforced the until-recently important fortification line along the western side of the City of David hill, because he recognized its continued defensive value against Sidetes' army.

90 Lipschitz 2012, 153.

91 Ussishkin 1979, 139.

92 Roughly where the Koan stamped handle was noted in note 65 .

93 Ussishkin 1979, 139.

94 Dąbrowa 2015, 28; see Fig. 1. 


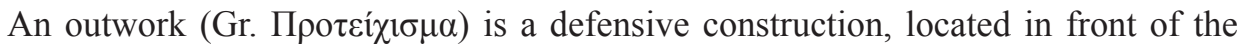
main fortification line. It serves the dual functions of exhausting the besiegers, and forestalling their advance to the key fortifications of the city. For lack of a better term, the "First Wall" functioned as an outwork to slow the Seleucid progress towards the more heavily populated quarter of Jerusalem, the City of David. Once inside the urban/ suburban space on the Southwestern Hill, the now internal western city-wall along the Tyropoeon Valley became for the besieging forces the last obstacle before they could complete their conquest of the city.

In describing the Roman general Pompey standing before Jerusalem in advance of his attack, Josephus describes Pompey as recognizing the likelihood that the inhabitants of the city would retreat to the Temple Mount after the city-wall itself was breached. ${ }^{95}$ For the latter siege of Titus, Josephus, in a lengthy narrative, recounted the battles before three fortification lines (70 AD) (Jos. BJ 5.302 [Third Wall], 331, 347 [Second Wall], and 6.250 [fortified Temple-Mount temenos]).

In sum, the most reasonable explanation for the archaeological evidence for a Seleucid siege of Jerusalem both at the David's Citadel courtyard and on the western side of the City of David hill is that, as a rule, the defenders of Jerusalem, in the time before Antiochus VII's advance on Jerusalem — as in the following two centuries - did not tear down "redundant" city-walls.

Of course, the evidence of fighting at David's Citadel could also reflect an attack on an as-yet-incomplete city-wall around the Southwestern Hill. That could be another explanation for the evidence for two sieges, and suit a time line according to which Hyrcanus, newly installed as High Priest, did not complete, or barely completed, the fortification of the Southwestern Hill when the Seleucid troops arrived. Effectively, the course of the fighting would have looked the same. The critical defensive point at David's Citadel would have had to be dispensed with before Antiochus' forces would have been able to cross the Tyropoeon Valley and proceed to the western side of the City of David and begin an assault there. On would assume that, upon the collapse of the David's Citadel defenses, Hyrcanus' forces there would have quickly retreated to the City of David hill, in order to reinforce those already there awaiting their most significant battle.

However, the weight of the evidence ${ }^{96}$ does not support the above as-yet-incomplete city-wall scenario.

To every rule there is an exception. Remarkably, the seeming rule that in Jerusalem "redundant" city-walls were not torn down is broken by the final wall that, the archaeological evidence argues, remained as a bulwark against attack on Jerusalem in 132 BC. I refer to the demolition and leveling operations at the GPL around the end of the second century BC. In spite of that exception, the literary and archaeological evidence supports the continued relevance of the "Second" Wall and the Temple temenos fortification until the total destruction of Jerusalem's defenses in 70 AD. ${ }^{97}$

95 "[Pompey] carefully considered the best method of attack. He noted the solidity of the walls and the formidable task of their assault, the frightful ravine in front of them, and within the ravine the temple also so strongly fortified as to afford, after the capture of the town, a second line of defense to the enemy" (Jos. BJ 1.141).

96 E.g., Geva's (2003, 530-532) stratigraphic analysis of the northern portion of the "First Wall" excavated in the Jewish Quarter.

97 Geva $(2018,43)$ correctly noted that parts of the "First Wall" remained in use even later than 70 AD. 


\section{Conclusions}

In this study, Jerusalem's physical growth in the second century BC, and the evidence for assaults on two western fortification lines of the city during Antiochus VII's siege, were presented. At the GPL, I suggest that it is the lower glacis that was attacked. One cannot know, but that may have been the moment when Hyrcanus opted for a face saving capitulation, and entered into negotiations with Antiochus VII. The wall, of which the GPL fortifications was a part, may not have been breached, thus sparing bloodshed within the City of David hill. The mediation bore fruit and the surrender was completed.

Later, after Sidetes' death in Media, the upper glacis was poured by Hyrcanus to reinforce the city-wall, improving its preparedness, although there is no evidence that that second glacis was ever assaulted. That second reinforcement operation seems to have remained standing until the end of the second-beginning of the first century $\mathrm{BC}-$ according to the dating of leveling operations after the GPL tower's demolition, using ceramic and coin evidence. With a functional wall around the City of David hill until that late date, one can argue that for the residents of the City of David, they had no need for the "First Wall" at that time. For them, only when there was no longer was a defensive line along the western side of the City of David hill would they have needed the "First Wall." But the "First Wall" was already standing, so the logic remained to keep the City of David western fortification at the ready.

Historical sources note no other threat to the city's security until Pompey's conquest in $64 \mathrm{BC} .{ }^{98}$ Therefore, as it turned out, the residents of the City of David did not need a city-wall to protect them from attack until $64 \mathrm{BC}$, so in hindsight, they did not need to strengthen the western city-wall with a new glacis after all.

The Antiochus VII siege of Jerusalem has played a large role in this study on the Hellenistic walls of Jerusalem. The recent source-critical analysis of a key source for the siege, the large assemblage of the kings' coin issues at the GPL, and the new evidence for Seleucid forces camped some distance from the city-walls have enabled us to gain a fuller picture of that episode. The battle between Antiochus VII and John Hyrcanus I caught the attention of a number of ancient writers, and these sources were repeated well into the Byzantine Period. ${ }^{99}$ Thanks to them, and the continuing archaeological revelations, we have been able to better understand Jerusalem's Hellenistic walls.

98 Jos. BJ 1.141-149; Cameron 2018.

99 Britt - Boustan (2017, 78-80) recently considered the Sidetes' siege their preferred interpretation for a mosaic panel on a fifth-century Galilean synagogue floor at Huqoq. 
AbBreviations

SC II/I - A. Houghton, C. Lorber, O. Hoover (2008), Seleucid Coins: A Comprehensive Catalogue; Seleucus IV through Antiochus XIII, vol. II, part I: Introduction, Maps and Catalogue, New YorkLancaster, PA-London.

TJC - Y. Meshorer (2001), A Treasury of Jewish Coins from the Persian Period to Bar Kochba, Jerusalem-Nyack, NY.

BIBLIOGRAPHY

Ariel, D. T. (1982), A Survey of Coin Finds in Jerusalem (until the End of Byzantine Period), Liber Annuиs 32: 273-326.

Ariel, D. T. (1990), Imported Stamped Amphora Handles, Coins, Worked Bone and Ivory, and Glass: Excavations at the City of David 1978-1985 Directed by Yigal Shiloh II (Qedem 30), Jerusalem.

Ariel, D. T. (2000), Imported Greek Stamped Amphora Handles, in: H. Geva (ed.), Jewish Quarter Excavations in the Old City of Jerusalem Conducted by Nahman Avigad, 1969-1982, vol. I: Architecture and Stratigraphy: Areas A, W and X-2. Final Report, Jerusalem: 267-283.

Ariel, D. T. (2003), Imported Amphora Fragments from Area A, in: H. Geva (ed.), Jewish Quarter Excavations in the Old City of Jerusalem Conducted by Nahman Avigad, 1969-1982, vol. II: The Finds from Areas $A, W$ and $X-2$, Jerusalem: 224-230.

Ariel, D. T. (2004), Stamped Handles, in: A. M. Maeir, D. Bahat (eds.), Excavations at Kikkar Safra (City Hall), Jerusalem 1989, 'Atiqot 47: 183-184.

Ariel, D. T. (2006), Coins, in: H. Geva (ed.), Jewish Quarter Excavations in the Old City of Jerusalem Conducted by Nahman Avigad, 1969-1982, vol. III: Area E and Other Studies: Final Report, Jerusalem: $192-217$.

Ariel, D. T. (2013), The Stamped Amphora Handles, in: D. Ben-Ami (ed.), Jerusalem: Excavations in the Tyropoeon Valley (Giv'ati Parking Lot) I (IAA Reports 52), Jerusalem: 327-337.

Ariel, D. T. (2015), A Stamped Amphora Handle from the Ophel, in: E. Mazar (ed.), The Ophel Excavations to the South of the Temple Mount: 2009-2013. Final Reports, vol. I, Jerusalem.

Ariel, D. T. (forthcoming a), John Hyrcanus I's First Autonomous Coins, in: A. M. Berlin, P. J. Kosmin (eds.), The Middle Maccabees: From the Death of Judas through the Reign of John Hyrcanus (ca. 160-104 BCE). New Archaeological and Historical Perspectives (SBL Archaeology and Biblical Studies Series).

Ariel, D. T. (2019), A Second Seleucid Coin Attributed to Jerusalem, Israel Numismatic Research 14: 41-73.

Ariel, D. T. (forthcoming b), The Stamped Amphora Handles from the City of David Excavations (1994-2012), in: R. Reich, The City of David Excavations, vol. I (IAA).

Ariel, D. T., De Groot, A. (2000), The Israelite Extramural Occupation at the City of David and Additional Considerations Regarding the Siloam Channel, in: D. T. Ariel (ed.), Excavations in the City of David Directed by Yigal Shiloh V: Extramural Areas (Qedem 40), Jerusalem: 155-169.

Atrash, W., Mazor, G., Aboud, H. (2018), A Phoenician / Hellenistic Sanctuary at Horbat Turit (Kh. et-Tantur), Journal of Hellenistic Pottery and Material Culture 3: 61-87.

Avigad, N. (1980), The Upper City of Jerusalem, Jerusalem (Hebrew). 
Bar-Kochva, B. (1989), Judas Maccabeus: The Jewish Struggle against the Seleucids, Cambridge.

Bar-Kochva, B. (1996), Pseudo-Hecataeus on The Jews: Legitimizing the Jewish Diaspora, BerkeleyLos Angeles-Oxford.

Bar-Kochva, B. (2010), The Image of the Jews in Greek Literature: The Hellenistic Period (Hellenistic Culture and Society 51), Berkeley-Los Angeles-London.

Bar Kochva, B. (2017), The Religious Persecutions of Antiochus Epiphanes as a Historical Reality, Tarbiz: A Quarterly for Jewish Studies 86: 395-444 (Hebrew).

Ben-Ami, D., Tchekhanovets, Y. (2015), “ “.. and they also that were in the city of David in Jerusalem, who had made themselves a tower" (1 Macc., 14.36). The Seleucid Fortification System at the Givati Parking Lot, City of David, in: G. D. Stiebel, O. Peleg-Barkat, D. Ben-Ami, Y. Gadot (eds.), New Studies in the Archaeology of Jerusalem and Its Region 9 (Hebrew), Jerusalem: 313-322.

Ben-Ami, D., Tchekhanovets, Y. (2016), "Then They Built Up the City of David with a High, Strong Wall and Strong Towers, and It Became Their Citadel," (I Maccabees 1:33), City of David Studies of Ancient Jerusalem 11: 19-29.

Britt, K. C., Boustan, R. S. (2017), The Elephant Mosaic Panel in the Synagogue at Huqoq: Official Publication and Initial Interpretations (JRA Supplementary Series 106), Portsmouth, Rhode Island.

Cameron, D. (2018), Towards a Re-Dating of Pompey's Conquest of Jerusalem, Journal of Jewish Studies 59: 225-247.

Dąbrowa, E. (2015), The "Camp of the Assyrians" and the Third Wall of Jerusalem, Scripta Judaica Cracoviensia 13: 19-30.

De Groot, A., Bernick-Greenberg, H. (2012), Excavations at the City of David 1978-1985 Directed by Yigal Shiloh VIIA: Area E: Stratigraphy and Architecture: Text (Qedem 53), Jerusalem.

Fagerlie, J. M. (1985): The Greek, Roman, Byzantine Arab, Crusader, and Modern Coins: Roman and Byzantine (G. C. Miles ed.), in: A. D. Tushingham, Excavations by K. M. Kenyon in Jerusalem 1961-1967, vol. I: Excavations in the Armenian Garden on the Western Hill, Toronto: 168-171.

Finkielsztejn, G. (1999), Hellenistic Jerusalem: The Evidence of the Rhodian Amphora Stamps, in: A. Faust, E. Barukh (eds.), New Studies on Jerusalem: Proceedings of the Fifth Conference, December $23^{\text {rd }} 1999$, Ramat Gan: 21*-36*.

Finkielsztejn, G. (2001), Chronologie détailée et révisée des éponymes amphoriques rhodiens de 270 à 108 av. J.-C. environ. Premier bilan, Oxford.

Finkielsztejn, G. (2006), Imported Amphoras, in: H. Geva (ed.), Jewish Quarter Excavations in the Old City of Jerusalem Conducted by Nahman Avigad, 1969-1982, vol. III: Area E and Other Studies: Final Report, Jerusalem: 168-183.

Finkielsztejn, G. (2008), Jerusalem, Sonnenfeld Street, Hadashot Arkheologiyot: Excavations and Surveys in Israel 120, http://www.hadashot-esi.org.il/report_detail_eng.aspx?id=935\&mag_id=114 (accessed: September 25, 2019).

Finkielsztejn, G. (2014), Amphoras from Area J, in: H. Geva (ed.), Jewish Quarter Excavations in the Old City of Jerusalem Conducted by Nahman Avigad, 1969-1982, vol. VI: Architecture and Stratigraphy: Areas J, N, Z and Other Studies: Final Report, Jerusalem: 212-228.

Finkielsztejn, G. (forthcoming), Hellenistic Amphora Types from El'ad, in: D. Amit, Y. Zelinger, I. Zilberbod (eds.), Hellenistic Farms at El'ad (Journal of Hellenistic Pottery and Material Culture, Supplemental Studies [Archaeopress]).

Geva, H. (1985), The "First Wall" of Jerusalem during the Second Temple Period - An ArchitecturalChronological Note, Eretz-Israel 18: 21-39 (Hebrew).

Geva, H. (2003), Summary and Discussion of Findings from Areas A, W and X-2, in: H. Geva (ed.), Jewish Quarter Excavations in the Old City of Jerusalem Conducted by Nahman Avigad, 19691982, vol. II: The Finds from Areas $A, W$ and $X-2$, Jerusalem: 501-552.

Geva, H. (2011), On the "New City" of Second Temple Period Jerusalem: The Archaeological Evidence, in: K. Galor, G. Avni (eds.), Unearthing Jerusalem: 150 Years of Archaeological Research in the Holy City, Grand Rapids, MI: 299-312. 
Geva, H. (2018), Hasmonean Jerusalem in the Light of Archaeology - Notes on Urban Topography, Journal of Hellenistic Pottery and Material Culture 3: 30-60.

Honigman, S. (2014), Tales of High Priests and Taxes: The Books of the Maccabees and the Judean Rebellion against Antiochos IV, Berkeley.

Kosmin, P. J. (2018), Time and Its Adversaries in the Seleucid Empire, Cambridge, MA-London.

Landes-Nagar, A. (2009), Jerusalem, Sha'are Moshe, Hadashot Arkheologiyot: Excavations and Surveys in Israel 121, http://www.hadashot-esi.org.il/report_detail_eng.aspx?id=1117\&mag_id=115 (accessed: October 6, 2019).

Lawrenz, J. C. (1985), The Jewish Coins, in: G. C. Miles (ed.), The Coins from the Armenian Garden, in: A. D. Tushingham, Excavations in Jerusalem 1961-1967, vol. 1, Toronto: 156-166.

Lipschitz, O. (2012), Between Archaeology and Text: A Reevaluation of the Development Process of Jerusalem in the Persian Period, in: M. Nissinen (ed.), Congress Volume Helsinki 2010 (Supplements to Vetus Testamentum 148), Leiden-Boston: 145-165.

Mazis, M., Wright, N. L. (2018), Archers, Antiochos VII Sidetes, and the $\leftleftarrows$ Arrowheads, Bulletin of the American Schools of Oriental Research 380: 205-229.

McLeod, W. (1965), The Range of the Ancient Bow, Phoenix 19: 1-14.

Reece, R., Brown, H., Butcher, K., Metcalf, M. D. (2008), Jerusalem: The Coins, in: K. Prag, Excavations by K. M. Kenyon in Jerusalem. 1961-1967, vol. V: Discoveries in Hellenistic to Ottoman Jerusalem Centenary Volume: Kathleen M. Kenyon 1906-1978 (Levant Supplementary Series 7), Oxford: 411-431.

Shalev, Y., Bocher, E., Roth, H., Sandhaus, D., Shalom, N., Gadot, Y. (forthcoming), New Evidence on the Nature and Location of Jerusalem during the Early Hellenistic Period, in: A. M. Berlin, P. J. Kosmin (eds.), The Middle Maccabees: From the Death of Judas through the Reign of John Hyrcanus (ca. 160-104 BCE). New Archaeological and Historical Perspectives (SBL Archaeology and Biblical Studies Series).

Simons, J. (1952), Jerusalem in the Old Testament. Researches and Theories (Studia Francisci Scholten memoriae dicata 1$)$, Leiden.

Sivan, R., Solar, G. (2000), Excavations in the Jerusalem Citadel, 1980-1988, in: H. Geva (ed.), Ancient Jerusalem Revealed, expanded ed., Jerusalem: 168-176.

Stiebel, G. D. (2013), Military Equipment, in: D. Ben-Ami, Jerusalem: Excavations in the Tyropoeon Valley (Giv'ati Parking Lot) I (IAA Reports 52), Jerusalem: 297-304.

Ussishkin, D. (1979), The 'Camp of the Assyrians' in Jerusalem, Israel Exploration Journal 29: 137142.

Zilberstein, A. (forthcoming), Hellenistic Military Architecture from the New Excavations in the Tyropoeon Valley, Jerusalem, in: A. M. Berlin, P. J. Kosmin (eds.), The Middle Maccabees: From the Death of Judas through the Reign of John Hyrcanus (ca. 160-104 BCE). New Archaeological and Historical Perspectives (SBL Archaeological and Biblical Studies Series).

Zilberstein, A. (2019), "On Your Walls, City of David": The Line of the Western Fortification of the City of David during in the Hellenistic Period, in Light of New Finds, New Studies in the Archaeology of Jerusalem and Its Region 13, 29-50 (Hebrew). 